\title{
Smelter : Inkonsistensi Kebijakan , Kendala dan Dampak di Indonesia
}

\author{
Maria Contesa $^{1}$, Sintaningrum², dan Mudiyati Rahmatunnisa ${ }^{3}$ \\ 1,2,3 Departemen Kebijakan Publik, Fakultas Ilmu Sosial dan Ilmu Politik, Universitas Padjadjaran, Bandung, Indonesia \\ mariacontesa85@gmail.com ${ }^{1}$ \\ sinta.ningrum@unpad.ac.id² \\ mudiyati.rahmatunnisa@unpad.ac.id ${ }^{3}$
}

\begin{abstract}
Abstrak
Penelitian ini dilakukan untuk mengetahui dampak kebijakan pembangunan Smelter di Indonesia dimana kebijakan yang sebelumnya mewajibkan perusahaan pertambangan untuk melakukan pengolahan dan pemurnian hasil pertambangan sebelum di jual ke pasar international. Namun dalam perjalanan kebijakan tersebut terjadi perubahan kebijakan selama kurun waktu 9 tahun ini dan perubahan tersebut telah memberikan dampak yang signifikan dalam pelaksanaannya. Metode yang digunakan dalam penelitian ini adalah menggunakan literature review yang berbagai dari surat kabar, peraturan-peraturan pemerintah, data-data kementerian serta data lainnya yang berhubungan dengan kegiatan smelter tersebut. berdasarkan hasil literature review. Berdasarkan hasil penelitian diketahui bahwa kebijakan smelter tersebut memberikan dampak yang baik bagi tenaga kerja dan pendapatan negara serta ekonomi dikawasan sekitar. Namun di sisi lain kebijakan pembangunan smelter yang berubah-ubah membuat perusahaan pertambangan menjadi malas untuk membangun dan menyebabkan kerugian bagi perusahaan dengan dikeluarkannya peraturan pememerintah nomor 1 tahun 2017 serta Permen ESDM nomor 5 dan 6 Tahun 2017.
\end{abstract}

Keyword : Smelter, Dampak Kebijakan, inkonsistensi.

\section{Pendahuluan}

Indonesia merupakan negara dengan penghasil barang tambang yang sangat besar. Jumlah kandungan mineral yang ada di Indonesia terdiri dari emas, timah, tembaga, perak, intan, batubara, minyak, bauksit, dan lainlain. (Asosiasi Pertambangan Indonesia, 2014) jumlah cadangan mineral di Indonesia menurut data pada table 1.

Tabel 1. Peringkat Mineral

\begin{tabular}{cccc}
\hline $\begin{array}{c}\text { Nama } \\
\text { Mineral }\end{array}$ & $\begin{array}{c}\text { Jumlah (\%) } \\
\text { dari cadangan } \\
\text { emas dunia }\end{array}$ & $\begin{array}{c}\text { Peringkat } \\
\text { dunia }\end{array}$ & $\begin{array}{c}\text { Peringkat } \\
\text { Produksi } \\
\text { Dunia }\end{array}$ \\
\hline Emas & 2,5 & 7 & 6 \\
\hline Timah & 8,1 & 5 & $\begin{array}{c}\text { (tidak } \\
\text { diketahui) }\end{array}$ \\
\hline Tembaga & 4,1 & 7 & 10,4 \\
\hline Nikel & 2,9 & 8 & 4 \\
\hline
\end{tabular}

Besarnya potensi yang di miliki Indonesia sedikit banyak memberikan angin segar dalam iklim investasi pertambangan. Jumlah investasi di bidang pertambangan dari tahun 2010 sampai 2014 mengalami pertumbuhan. Pada tahun 2010 jumlah investasi US\$ 4.373 Juta.
Sedangkan sampai 2014 naik menjadi US\$ 7.430 Juta (Rencana Strategis Direktorat Jenderal Mineral dan Batubara, 2015-2019).

Seiring dengan berkembangnya investasi pertambangan tersebut mengakibatkan jumlah produksi semakin meningkat.

Tabel. 2 Produksi Mineral Utama 2010-2014

\begin{tabular}{|c|c|c|c|c|c|c|c|}
\hline \multirow{2}{*}{ No. } & \multirow{2}{*}{ Komoditas } & \multirow{2}{*}{ Unit } & \multicolumn{5}{|c|}{ Realisasi } \\
\hline & & & 2010 & 2011 & 2012 & 2013 & 2014 \\
\hline 1. & Logam Tembaga & Ribu Ton & 878 & 543 & 448 & 450 & 416 \\
\hline 2. & Emas & Ton & 104 & 76 & 75 & 59 & 67 \\
\hline 3. & Timah & Ribu Ton & 48 & 42 & 95 & 88 & 74 \\
\hline 4. & Bijih Nikel & Juta Ton & 7 & 32 & 41 & 60 & 3,9 \\
\hline 5. & Bijih Bauksit & Juta Ton & 16 & 39 & 30 & 56 & 2,8 \\
\hline 6. & $\begin{array}{l}\text { Bijih dan Pasir } \\
\text { Besi }\end{array}$ & Juta Ton & 4 & 12 & 10 & 19 & 1,2 \\
\hline
\end{tabular}

Selain itu semakin produksi meningkat maka ekspor terhadap mineral mentah (ore) mengalami kenaikan juga. Berdasarkan data dari Direktorat Jenderal Mineral dan Batubara diketahui bahwa terjadi kenaikan yang signifikan dalam ekspor dari kurun waktu 2008 sampai 2011. Hal ini dikarenakan belum diberlakukannya kebijakan yang mengatur kegiatan pengolahan pemurnian 
pada sektor tersebut. diketahui bahwa ekspor untuk masing -masing komoditas mengalami kenaikan seperti contoh nikel mengalami kenaikan 8 kali lipat, dilanjut dengan bijih besi dan pasir besi naik menjadi 7 kali lipat, bijih tembaga 11 kali lipat, dan bauksit meningkat 5 kali lipat (Rencana Strategis Direktorat Jenderal Mineral dan Batubara, 2015-2019). Tentunya jika mineral tersebut di ekspor keluar dalam bentuk mineral mentah (ore) maka nilai yang didapatkan akan lebih kecil dibandingkan dengan dilakukan pengolahan pemurnian (Smelting) terlebih dahulu.

Oleh karena itu pemerintah mengeluarkan kebijakan peningkatan nilai tambah melalui UndangUndang Pertambangan Nomor 4 tahun 2009 dimana didalamnya mengatur kewajiban pengolahan pemurnian untuk mineral mentah sebelum dilakukan ekspor (Undang-undang Pertambangan Nomor 4 Tahun 2009 tentang Pertambangan Mineral dan Batubara, 2009). Dalam kebijakan tersebut pada pasal 102 dan 103 dimana didalamnya menyatakan bahwa:

"Pemegang IUP dan IUPK wajib meningkatkan nilai tambah sumber daya mineral dan/atau batubara dalam pelaksanaan penambangan, pengolahan dan pemurnian, serta pemanfaatan mineral dan batubara."

Namun dalam perjalannya kebijakan tersebut memberikan dampak yang beragam bagi perusahaan pertambangan dan perusahaan smelter, hal ini dikarenakan ketidakkonsistenan pemerintah dalam menerapkan kebijakan tersebut seiring berubahnya

Kemudian dibuatlah kebijakan turunannya untuk dapat mengatur teknis kebijakannya melalui peraturan pemerintah nomor 23 Tahun 2010 dimana pada Peraturan pemerintah tersebut mengatur tentang pelaksanaan kegiatan usaha pertambangan. Kebijakan smelter ini mengalami perubahan terus menerus. Bahkan, Peraturan Menteri ESDM baru dikeluarkan dua tahun kemudian yaitu pada tanggal 6 Februari 2012. Peraturan Menteri ESDM No. 7 Tahun 2012 yang di dalamnya mengatur kadar kemurnian ini mengalami dua kali revisi, masingmasing dengan Peraturan Menteri ESDM Nomor 11 Tahun 2012 pada 6 Mei 2012 dan Peraturan Menteri ESDM No. 20 Tahun 2013 pada 1 Agustus 2013.

Menjelang larangan ekspor mineral mentah pemerintah melakukan revisi kembali untuk yang kedua pada Peraturan Pemerintah No. 23 Tahun 2010 melalui Peraturan pemerintah nomor 1 tahun 2014 tentang Peningkatan Nilai Tambah Mineral Melalui Kegiatan Pengelolaan dan Pemurnian Mineral Dalam Negeri melalui Pasal 12 ayat 5 ditetapkan bahwa batas akhir kebijakan-kebijakan pelaksananya. Penelitian ini sangat penting dilakukan untuk memberikan masukan kepada pemerintah bagaimana kebijakan yang dikeluarkan berdampak signifikan.

\section{Metode Penelitian}

Metode Penelitian dalan jurnal ini menggunakan literature review dari berbagai sumber yaitu berdasarkan data di Kementerian Energi dan Sumber Daya Mineral pada direktorat Jenderal Mineral dan Batubara, kemudian data dari Asosiasi Penambang Indonesia , Asosiasi Perusahaan Industri Pengolahan dan Pemurnian Indonesia (AP3I) serta sumber berita online lainnya.

\section{Pembahasan}

\subsection{Sejarah Kebijakan Smelter di Indonesia}

Kebijakan smelter bergulir seiring di sah kannya undang-undang pertambangan yang baru pada tahun 2009. Melalui undang-undang pertambangan nomor 4 tahun 2009 pemerintah mewajibkan bagi perusahaan pertambangan untuk dapat melakukan pengolahan pemurnian mineral mentah sebelum di jual ke luar negeri. Pada Pasal 103 juncto Pasal 170 secara tegas diperintahkan kepada setiap pemegang Izin Usaha Pertambangan (IUP) dan Izin Usaha Khusus (termasuk Kontrak Karya) untuk "wajib” membangun pabrik smelter (pengolahan dan pemurnian mineral) di Indonesia selambat-lambatnya lima tahun setelah UU Minerba/2009 diundangkan pada tanggal 12 Januari 2009.

pembangunan smelter diperpanjang kembali menjadi paling lambat tiga tahun sejak dikeluarkan pada tanggal 11 Januari 2014.

Jika kita telaah dari kebijakan tersebut terlihat pemerintah memberikan ruang kembali untuk ekspor mineral bagi perusahaan pertambangan karena sampai 2014 kebijakan tersebut terus mengalami revisi dan perubahan serta membuka kesempatan ekspor mineral mentah dengan memperpanjangnya. Dan sampai tahun 2017 pemerintah mengeluarkan kembali peraturan pemerintah untuk memperpanjang kembali 5 (lima) tahun kegiatan ekspor mineral mentah melalui peraturan pemerintah nomor 1 tahun 2017 dan pada Permen ESDM nomor 5 dan 6 tahun 2017. Jika kita lihat berjalannya kebijakan tersebut dapat terlihat pemerintah seperti tidak serius dalam menjalankan amanat Undang-undang. Hal ini lah yang menyebabkan kebingungan para stake holder dalam hal ini perusahaan pertambangan dan pengusaha smelter, serta pemerintah sendiri yang memperlambat kebijakan kewajiban smelter tersebut. perubahan kebijakan yang terjadi bukan pada kejelasan kapan batas waktu yang pasti akan di laksanakannya penutupan ekspor 
mineral mentah dan sanksi yang tegas yang harus diberikan ketika perusahaan tidak patuh terhadap undangundang pertambangan.

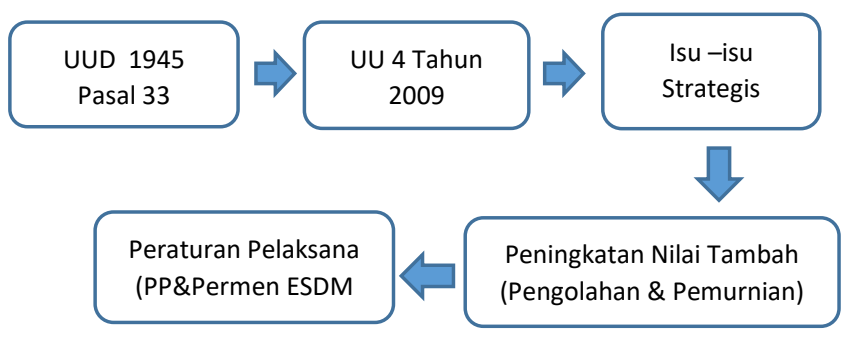

Gambar 1. Konstruksi Hukum Tata Kelola SDA yang Ideal

\subsection{Kendala Pembangunan Smelter}

Dalam Proses pembangunan smelter tentunya ada kendala-kendala yang harus dihadapi oleh para stake holder yaitu seperti perijinan, Modal, bahan baku, dan lain-lain.

\subsubsection{Perijinan Pembangunan Smelter}

Perijinan dalam pembangunan smelter dirasa cukup rumit bagi para investor. Hal ini dengan banyaknya persyaratan yang harus dipenuhi sedikit banyak memberikan pengaruh bagi para investor.

Investor merasa bahwa perijinan pembangunan smelter dirasa masih cukup rumit dan sulit. Hal ini menjadi salah satu kendala sulit berkembangnya investasi di bidang smelter. (KEMENPERIN RI, 2017).

Berdasarkan data diketahui bahwa persyaratan pembangunan smelter memiliki beberapa kriteria yang harus dipenuhi oleh para investor yang baru akan membangun yaitu:

1 Melampirkan surat permohonan pengajuan IUP OPK Pengolahan dan Pemurnian;

2 Melengkapi keterangan di dalam formulir pengajuan IUP OPK Pengolahan dan Pemurnian; dan

3 Melengkapi checklist dokumen permohonan pengajuan IUP OPK Pengolahan dan Pemurnian. Untuk dokumen yang harus dipenuhi terlampir dalam table di bawah ini .

Tabel. 3 Kelengkapan Dokumen

\begin{tabular}{llll}
\hline NO & & Dokumen & \multicolumn{2}{c}{ Kelengkapan } \\
\hline 1. & Profil Perusahaan dengan & Akta Pendirian dan \\
& mencantumkan : & & Perubahan Perusahaan ( \\
& & Pertambangan dan \\
& & Perdagangan -komoditas \\
& & yang dituju, susunan direksi \\
\hline
\end{tabular}

\begin{tabular}{|c|c|c|}
\hline NO & Dokumen & Kelengkapan \\
\hline & & $\begin{array}{l}\text { perusahaan, pemegang } \\
\text { saham) }\end{array}$ \\
\hline & & $\begin{array}{l}\text { Nomor Pokok Wajib Pajak } \\
\text { (NPWP) }\end{array}$ \\
\hline & & SIUP \\
\hline & & Surat Keterangan Domisili \\
\hline & & Tanda Daftar Perusahaan \\
\hline & & $\begin{array}{l}\text { Pengesahan Akta Pendirian } \\
\text { Perusahaan dari yang } \\
\text { berwenang }\end{array}$ \\
\hline \multirow[t]{11}{*}{2.} & $\begin{array}{l}\text { Memorandum of } \\
\text { Understanding } \\
\text { (MOU)/perpanjangan jual beli } \\
\text { antara Pemohon IUP Operasi } \\
\text { Produksi Khusus dengan } \\
\text { Pemegang IUP Operasi } \\
\text { Produksi yang Masih Berlaku }\end{array}$ & $\begin{array}{l}\text { Spesifikasi Bahan Galian, } \\
\text { Volume (Tonase), Jangka } \\
\text { waktu MOU/perjanjian, } \\
\text { Materai }\end{array}$ \\
\hline & $\begin{array}{l}\text { MOU/Perjanjian } \\
\text { Beli/Purchase order antara } \\
\text { pemohon IUP Operasi } \\
\text { Produksi Khusus dengan } \\
\text { Pembeli (End User) yang } \\
\text { masih berlaku }\end{array}$ & $\begin{array}{ll}\text { Spesifikasi bahan } & \text { galian, } \\
\text { volume (tonase), tujuan } \\
\text { penjualan, jangka } \\
\text { MU/Perjanjian }\end{array}$ \\
\hline & $\begin{array}{l}\text { Legalitas IUP Produk SK IUP } \\
\text { Operasi Produksi yang telah } \\
\text { terlegalisir di Direktorat } \\
\text { Jenderal Mineral dan Batubara } \\
\text { / Clean and Clear (CNC) } \\
\text { dilampirkan }\end{array}$ & \\
\hline & $\begin{array}{l}\text { Data Teknis Pemilik tambang } \\
\text { / IUP Operasi Produksi } \\
\text { (Cadangan/Sumber daya- } \\
\text { Kapasitas Produksi), Surat } \\
\text { Persetujuan Amdal atau FS/ } \\
\text { Studi Kelayakan }\end{array}$ & \\
\hline & $\begin{array}{l}\text { Laporan Finansial Perusahaan } \\
\text { Pemegang IUP Operasi }\end{array}$ & $\begin{array}{ll}\text { - } & \text { Bukti Pembayaran } \\
\text { Iuran tetap 3(tiga) } \\
\text { tahun terakhir } \\
\text { - } \begin{array}{ll}\text { Bukti pembayaran } \\
\text { royalty } 3 & \text { (tiga) tahun } \\
\text { terakhir }\end{array} \\
\end{array}$ \\
\hline & $\begin{array}{l}\text { Perijinan Industri/perijinan } \\
\text { berdirinya pabrik }\end{array}$ & \\
\hline & $\begin{array}{l}\text { Laporan } \\
\text { Perusahaan } 3 \text { tahun terakhir }\end{array}$ & \\
\hline & $\begin{array}{l}\text { Laporan RKAB tahun terakhir } \\
\text { ( dilegalisir dari dinas } \\
\text { pertambangan setempat) }\end{array}$ & \\
\hline & $\begin{array}{l}\text { Persetujuan AMDAL atau } \\
\text { UKL/UPL }\end{array}$ & \\
\hline & $\begin{array}{l}\text { Persetujuanstudi kelayakan } \\
\text { pabrik yang dikeluarkan oleh } \\
\text { pejabat setempat }\end{array}$ & \\
\hline & Daftar tenaga ahli & \\
\hline
\end{tabular}

Hal tersebutlah salah satu factor yang membuat investor kurang tertarik dengan investasi di bidang smelter tersebut.

Ketidak konsistenan pemerintah dalam penerapan kebijakan smelter juga sedikit banyak membuat perusahaan smelter menjadi malas untuk membangun. Hal tersebut juga terjadi di negara Filipina dimana terjadi ketidakkonsistenan dari pemerintah dalam membuat 
kebijakan (Ofreneo, 2009). Indonesia sendiri sampai saat ini sudah melakukan perubahan terkait peraturan smelter sebanyak 4 (empat) kali perubahan dalam kurun waktu 9 tahun. Bisa di lihat pada tabel 4. Indonesia merupakan negara dengan sumber daya alam yang sangat melimpah, namun keberadaannya tidak diikuti dengan kebijakannya yang efektif (Dutu, 2016).

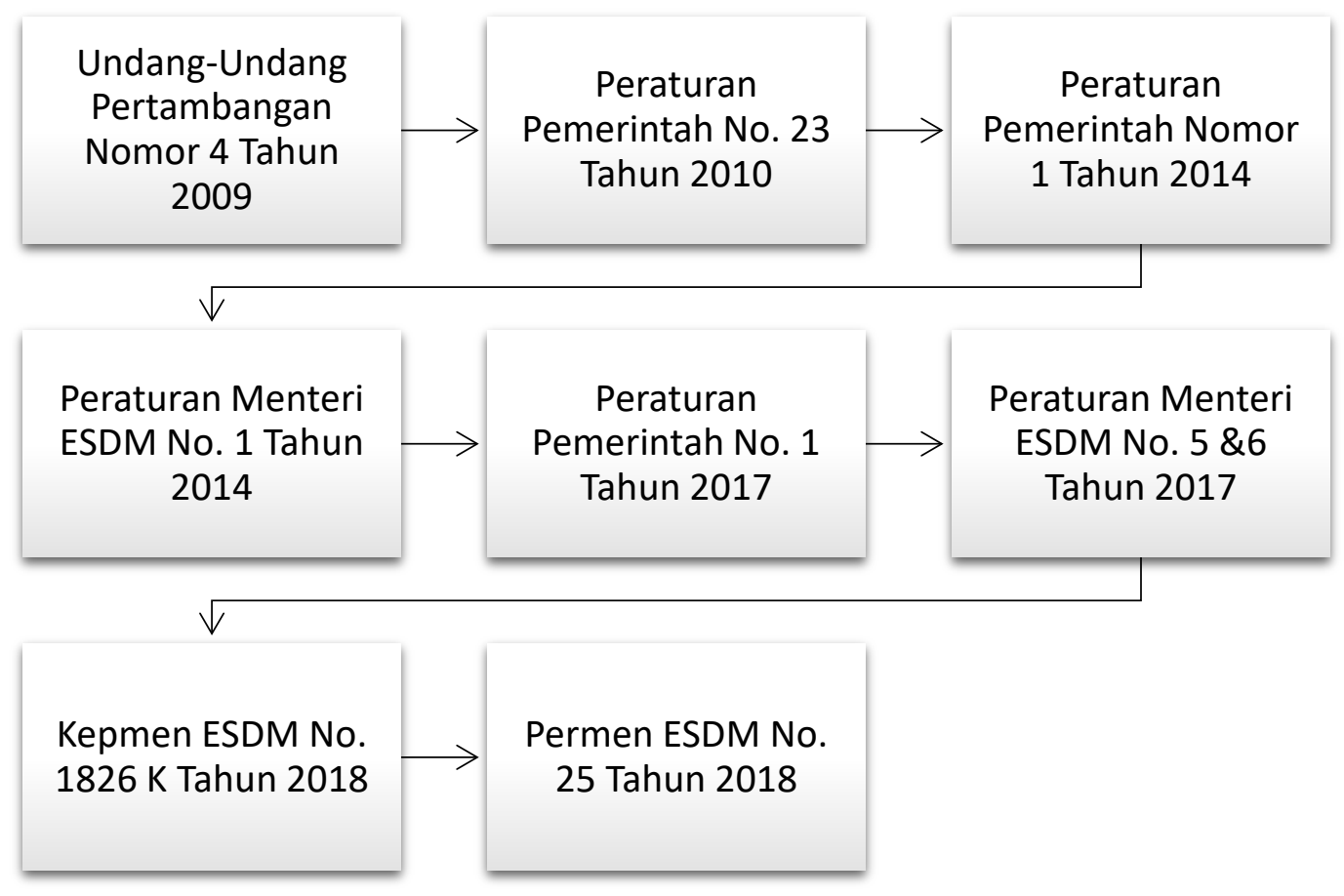

Gambar 2. Peraturan Mengenai Smelter Kurun waktu 9 (Sembilan ) Tahun

\subsubsection{Intervensi Politik}

\subsubsection{Modal Pembangunan Smelter}

Untuk modal sendiri tentunya dalam pembuatan smelter memerlukan dana yang sangat besar. Jumlah investasi Smelter Nikel mencapaiUS\$5,03 miliar atau Rp.68 triliun dari Januari Hingga Oktober 2017 (Bisnis Indonesia , Desember). Tentunya investasi di sektor smelter tidak sedikit sehingga banyak investor kurang tertarik.

\subsubsection{Bahan Baku Smelter}

Ketersediaan Bahan baku menjadi salah satu hal yang penting bagi smelter. Hal ini lah yang di inginkan oleh perusahan dan investor yaitu jaminan bahan baku yang pasti dari pemerintah. Jika bahan baku tidak dapat dipastikan bagaimana industry tersebut dapat tumbuh di masa yang akan datang.
Adanya intervensi kepentingan sering menjadi alasan kuat adanya ketidak konsistenan pemerintah dalam penegakan aturan smelter hal tersebut terlihat dengan dibukanya kembali keran eksport tentunya

akan menguntungkan beberapa pihak terutama perusahanperusahaan besar.

Seperti yang terjadi pada tahun 2015 kasus tentang “ Papa Minta Saham “ dimana didalamnya terjadi praktek pungli yang menyeret salah satu ketua umum partai Golkar yang akhirnya resmi mengundurkan diri (Merdeka, 2015). Tentunya sangat disayangkan sekali praktikpraktik pungli tersebut sehingga mencoreng dunia pertambangan dan hokum di negara kita ini.

\subsection{Sanksi Bagi Perusahaan yang Tidak Membuat Smelter}


Adapun sanksi yang di sampaikan bagi perusahaan yang tidak membangun smelter yaitu akan dilakukan sanksi finansial dimana $20 \%$ nilai ekspor mineral mentah akan kena denda (KONTAN, 2018). Hal ini tertuang dalam Permen ESDM nomor 25 Tahun 2018 pada pasal 55 ayat 8. Dengan adanya sanksi tersebut diharapkan pemerintah dapat menggenjot pembangunan smelter-smelter yang sebelumnya terbengkalai.

\subsection{Dampak Kebijakan Smelter}

Dampak kebijakan smelter sendiri menghasilkan dampak di masyarakat baik positif maupun negative. Tentunya dengan adanya smelter diharapkan dapat memberikan efek positif bagi iklim investasi di Indonesia. Sampai dengan tahun 2018 sudah terbangun 12 smelter di Indonesia. Adapun dampak positif dari di berlakukannya kebijakan smelter tersebut maka :

1 Pemanfaatan tenaga kerja yang cukup besar sehingga dapat mengurangi pengangguran di Indonesia. Berdasarkan data lapangan pemerintah telah menyiapkan 1200 tenaga kerja dari tahun 2015-2017 untuk dipekerjakan di pabrik smelter tersebut yang berasal dari SMK dan Politeknik industry logam dan lainnya (KEMENPERIN RI, 2018). Tentunya dengan adanya smelter tersebut dapat mengurangi angka pengangguran di Indonesia seiring dengan naiknya investasi di bidang tersebut. namun perlu di lakukan pengawasan terhadap pekerja asing lainnya yang ada dimana ada perusahaan pertambangan yang menggunakan pekerja dari china untuk proyek tersebut. keberadaan pemerintah sebagai regulator diharapkan dapat pengatur keberadaan para pekerja asing jangan sampai terjadi gesekan , meskipun pekerja asing tersebut hanya bekerja untuk membangun proyek tersebut ataupun pekerja asing tersebut memiliki keahlian tertentu. Pemerintah harus dapat mengawal dan memberikan pendidika bagi masyarakat agar gap antara pekerja asing dan local tidak saling mematikan satu sama lain.

2 Pendapatan negara meningkat seiring dengan adanya kebijakan smelter. Tentunya dengan kenaikan nilai value dari mineral tersebut maka akan meningkatkan pendapatan negara.

3 Perekonomian daerah lokasi smelter tentunya akan berkembang pula dengan adanya aktifitas di lokasi tersebut membuka lapangan pekerjaan baru untuk masyarakat sekitar serta memberikan penghidupan masyarakat tersebut melalui perekonomia dengan berdagang.

Disamping dampak positif yang dihasilkan tentunya kebijakan smelter yang sering berubah-ubah memberikan dampak negative juga bagi perusahaan pertambangan yaitu ketidak konsistenan dalam kebijakan smelter membuat tak sedikit perusahaan smelter dalam negeri merugi . seperti dilansir dalam situs berita online (Berita Satu, 2017) bahwa sebanyak 11 smelter mengalami kerugian yang di akibatkan oleh kebijakan yang dikeluarkan pemerintah lewat Permen ESDM nomor 6 tahun 2017. Dimana kebijakan tersebut mempengaruhi harga nikel dunia sehingga harga nikel sempat anjlok di harga US\$ 9.800/Ton dimana sebelumnya harga nikel berada di kisaran US\$12.000 / Ton. Tentunya dengan anjloknya nilai tersebut tidak sebanding dengan biaya produksi perusahaan smelter di Indonesia. Berbeda hal nya dengan negara-negara lain yang sudah memiliki teknologi yang lebih canggih tentunya biaya produksi nikel tersebut akan lebih rendah dan penurunan harga tersebut tidak begitu berpengaruh banyak. Dan sampai 2018 terdapat 2 smelter yang telah berhenti beroperasi dikarenakan teknologi yang tidak memunginkan dan bahan baku yang mahal. Hal ini tentunya harus menjadi perhatian pemerintah dalam membuat kebijakan untuk memberikan kepastian akan bahan baku serta membantu dalam memberikan informasi teknologi guna mendukung industry smelter tersebut dapat sustainable.

\section{Kesimpulan}

Kewajiban pembangunan Smelter sangat baik untuk di terapkan di Indonesia dengan banyak sumber daya alam yang ada. namun perlu di ingat bahwa konsistensi pemerintah dalam mengeluarkan kebijakan perlu untuk di tinjau ulang karena setiap kebijakan yang dikeluarkan tentunya akan berimbas pada pelaku sektor tersebut. dalam hal ini pelaku industry smelter berpendapat bahwa pemerintah seperti tidak serius dalam mengatur kebijakan smelter tersebut dengan. Kebijakan kebijakan yang ada selama ini tidak sesuai dengan amanat undang-undang pertambangan dimana pemerintah menjadi lemah dalam implementasi terhadap kebijakan tersebut.

Sehingga mengakibatkan dampak yang besar bagi perusahaan-perusahaan salah satunya dengan dikeluarkannya kebijakan tersebut telah memicu nilai harga mineral (nikel) anjlok dan menyebabkan kerugian di sektor tersebut.

Selain itu sanksi yang selama ini tidak jelas menambah kebijakan yang dikeluarkan menjadi omong kosong belaka. Melalui Permen ESDM nomor 25 Tahun 2018 pada pasal 55 ayat 8 pemerintah mulai berusaha untuk memberikan sanksi yang tegas namun diharapkan sanksi tersebut dapat menjadi dorongan bagi peruahaan untuk dapat membangun smelter. Evaluasi perlu dilakukan sehingga penerapan sanksi tersebut dapat dilaksanakan dengan baik karena tanpa ada aturan yang mengikat dan sanksi yang jelas tentunya keseriusan 
pemerintah menjadi pertanyaan. Pada penelitian ini penulis belum sampai mengukur nilai manfaat yang di dapat dari mineral yang dilakukan proses pengolahan dan pemurnian tersebut. Baiknya penelitian selanjutya dapat meneliti terkait cost benefit analysis dari pembangunan smelter tersebut sehingga akan diketahui nilai manfaat dari kebijakan yang dikeluarkan oleh pemerintah tersebut.

\section{References}

Asosiasi Pertambangan Indonesia. (2014, Mei 28). Potensi dan tantangan pertambangan indonesia. Retrieved from Indonesian Mining Association: https://www.imaapi.com/index.php?option=com_content\&view= article\&id=1937: potensi-dan-tantanganpertambangan-di-indonesia\&catid $=47$ : medianews\&Itemid=98\&lang=id

Berita Satu. (2017, Juni 5). Berita satu. Retrieved from Beritasatu.com: http://id.beritasatu.com/tajuk/konsisten-denganhilirisasi/161034

Bisnis Indonesia . (Desember, Desember 27). Hingga Oktober 2017, Nilai Investasi Smelter Nikel US\$5,03 Miliar. Jakarta, Indonesia.

Dutu, R. (2016). Challenges andpolicies in Indonesia's energy sector. Energy Policy.

KEMENPERIN RI. (2017, 7 25). Kemenperin.go.id. Retrieved from Kementerian Perindustrian Republik Indonesia: http://www.kemenperin.go.id/artikel/6942/Paso kan-Energi-Ganjal-Pembangunan-Smelter

KEMENPERIN RI. (2018). kemenperin.go.id. Retrieved from Kementerian Perindustrian Republik Indonesia: http://www.kemenperin.go.id/artikel/17560/Ke menperin-Pasok-1.200-SDM-Industri-Smelter

Kementerian ESDM. (2018, Mei 15). Permen ESDM No.25 Tahun 2018. Regulation . Jakarta, DKI Jakarta, Indonesia.
Kementerian ESDM . (2018, Mei 25). Peraturan Mentri. Jakarta, DKI Jakarta, Indonesia.

KONTAN. (2018, Mei 15). Retrieved from kontan.co.id: https://industri.kontan.co.id/news/sanksifinansial-dalam-pembangun-smelter-menuaikritik

Merdeka. (2015, Desember 17). Merdeka.com. Retrieved from merdeka website:

https://www.merdeka.com/peristiwa/kronologislengkap-kasus-papa-minta-saham-sampai-bikinsetnov-mundur.html

Ofreneo, R. E. (2009). Failur to launch : Industrialisation in metal rich philippines. Journal of The Asia Pasific Economy.

Peraturan Menteri ESDM. (2014, Januari 11). Peraturan Menteri ESDM tentang Peningkatan Nilai Tambah Mineral Melalui Kegiatan Pengolahan dan Pemurnian Mineral Di Dalam Negeri. DKI Jakarta, Indonesia .

Rencana Strategis Direktorat Jenderal Mineral dan Batubara. (2015-2019). Rencana Strategis Direktorat Jenderal Mineral dan Batubara. Jakarta: Dirjen Minerba.

Undang-undang Pertambangan Nomor 4 Tahun 2009 tentang Pertambangan Mineral dan Batubara. (2009, Januari 12). Jakarta, DKI Jakarta, Indonesia. 